\title{
Distribution and establishment of the alien Australian redclaw crayfish, Cherax quadricarinatus, in South Africa and Swaziland
}

\author{
Ana L Nunes ${ }^{\text {Corresp., }}{ }^{1,2,3}$ ， Tsungai A Zengeya ${ }^{4}$ ， Andries C Hoffman ${ }^{5}$ ， G John Measey ${ }^{1}$ ， Olaf LF Weyl ${ }^{2}$ \\ ${ }^{1}$ Centre for Invasion Biology, Department of Botany and Zoology, University of Stellenbosch, Stellenbosch, South Africa \\ 2 Centre for Invasion Biology, South African Institute for Aquatic Biodiversity, Grahamstown, South Africa \\ 3 Invasive Species Programme, South African National Biodiversity Institute, Kirstenbosch Research Centre, Cape Town, South Africa \\ 4 South African National Biodiversity Institute, Kirstenbosch Research Centre, Cape Town, South Africa \\ 5 Mpumalanga Tourism and Parks Agency, Nelspruit, South Africa \\ Corresponding Author: Ana L Nunes \\ Email address: ananunes@sun.ac.za
}

Background. The Australian redclaw crayfish (Cherax quadricarinatus, von Martens), is native to Australasia but has been widely translocated around the world due to the aquaculture and aquarium trade. Mostly as a result of escape from aquaculture facilities, this species has established extralimital populations in Australia and alien populations in Europe, Asia, Central America and Africa. In South Africa, C. quadricarinatus was first sampled from the wild in 2002 in the Komati River, following its escape from an aquaculture facility in Swaziland, but data on the current status of its populations is not available.

Methods. To establish a better understanding of its distribution, rate of spread and population status, we surveyed a total of 46 sites in various river systems in South Africa and Swaziland. Surveys were performed between September 2015 and August 2016 and involved visual observations and the use of collapsible crayfish traps.

Results. Cherax quadricarinatus is now present in the Komati, Lomati, Mbuluzi, Mlawula and Usutu rivers, and it was also detected in several off-channel irrigation impoundments. Where present, it was generally abundant, with populations having multiple size cohorts and containing ovigerous females. In the Komati River, it has spread over more than $112 \mathrm{~km}$ downstream of the initial introduction point and $33 \mathrm{~km}$ upstream a tributary, resulting in a minimum spread rate of $8 \mathrm{~km}$ year ${ }^{-1}$ downstream and 4.7 $\mathrm{km}$. year $^{-1}$ upstream. In Swaziland, estimated downstream spread rate might reach $14.6 \mathrm{~km}$.year ${ }^{-1}$. Individuals were generally larger and heavier closer to the introduction site which might be linked to juvenile dispersal.

Discussion. These findings demonstrate that $C$. quadricarinatus is established in South Africa and Swaziland and that the species has spread, not only within the river where it was first introduced but also between rivers. Considering the strong impacts that alien crayfish usually have on invaded ecosystems, assessments of its potential impacts on native freshwater biota and an evaluation of possible control measures are, therefore, urgent requirements. 
1 Distribution and establishment of the alien Australian redclaw crayfish, Cherax

2 quadricarinatus, in South Africa and Swaziland

3 Ana L Nunes ${ }^{1,2,3}$, Tsungai A Zengeya ${ }^{4}$, Andries C Hoffman ${ }^{5}$, G John Measey ${ }^{1}$, Olaf LF Weyl ${ }^{2}$

4

$5{ }^{1}$ Centre for Invasion Biology, Department of Botany and Zoology, Stellenbosch University,

6 South Africa

$7{ }^{2}$ Centre for Invasion Biology, South African Institute for Aquatic Biodiversity, Grahamstown,

8 South Africa

$9{ }^{3}$ Invasive Species Programme, South African National Biodiversity Institute, Kirstenbosch

10 Research Centre, South Africa

$11{ }^{4}$ South African National Biodiversity Institute, Kirstenbosch Research Centre, South Africa

$12{ }^{5}$ Mpumalanga Tourism and Parks Agency, Nelspruit, South Africa

13

14 Corresponding Author:

15 Ana L. Nunes ${ }^{1,2,3}$

16

17 E-mail address: ananunes@sun.ac.za 
18 Abstract

19 Background. The Australian redclaw crayfish (Cherax quadricarinatus, von Martens), is native

to Australasia but has been widely translocated around the world due to the aquaculture and aquarium trade. Mostly as a result of escape from aquaculture facilities, this species has established extralimital populations in Australia and alien populations in Europe, Asia, Central America and Africa. In South Africa, C. quadricarinatus was first sampled from the wild in 2002 in the Komati River, following its escape from an aquaculture facility in Swaziland, but data on the current status of its populations is not available.

Methods. To establish a better understanding of its distribution, rate of spread and population status, we surveyed a total of 46 sites in various river systems in South Africa and Swaziland. Surveys were performed between September 2015 and August 2016 and involved visual observations and the use of collapsible crayfish traps.

Results. Cherax quadricarinatus is now present in the Komati, Lomati, Mbuluzi, Mlawula and Usutu rivers, and it was also detected in several off-channel irrigation impoundments. Where present, it was generally abundant, with populations having multiple size cohorts and containing ovigerous females. In the Komati River, it has spread over more than $112 \mathrm{~km}$ downstream of the initial introduction point and $33 \mathrm{~km}$ upstream a tributary, resulting in a minimum spread rate of 8 km.year-1 downstream and 4.7 km.year ${ }^{-1}$ upstream. In Swaziland, estimated downstream spread rate might reach $14.6 \mathrm{~km}$.year ${ }^{-1}$. Individuals were generally larger and heavier closer to the introduction site which might be linked to juvenile dispersal.

Discussion. These findings demonstrate that $C$. quadricarinatus is established in South Africa and Swaziland and that the species has spread, not only within the river where it was first introduced but also between rivers. Considering the strong impacts that alien crayfish usually 
41 have on invaded ecosystems, assessments of its potential impacts on native freshwater biota and

42 an evaluation of possible control measures are, therefore, urgent requirements. 


\section{Introduction}

Freshwater crayfish have been introduced globally, mostly for aquaculture and ornamental purposes, but generally their subsequent invasions have resulted in more ecosystem losses than benefits (Lodge et al., 2012). Continental Africa contains no native freshwater crayfish species, but three Australasian Parastacidae species, the Australian redclaw crayfish (Cherax quadricarinatus, von Martens), the smooth marron (Cherax cainii Austin and Ryan) and the yabby (Cherax destructor Clark), and a single North American Cambaridae species, the red swamp crayfish (Procambarus clarkii Girard), have been introduced (Boyko, 2016). All four species have been introduced into South Africa, but only P. clarkii and C. quadricarinatus seem to have successfully established wild populations (Schoonbee, 1993; van Rooyen, 2013). Although $P$. clarkii has been introduced to several African countries and caused visible impacts (Lowery \& Mendes, 1977; Mikkola, 1996; Foster \& Harper, 2006), in South Africa the species is only known from a single locality and does not seem to be spreading (Nunes et al., 2017). Populations of C. quadricarinatus are more widespread in the country (du Preez \& Smit, 2013; van Rooyen, 2013; Coetzee et al., 2015; de Villiers, 2015) and have also been reported from Swaziland (de Moor, 2002), Zimbabwe (Marufu, Phiri \& Nhiwatiwa, 2014), Zambia and Mozambique (Chivambo, Nerantzoulis \& Mussagy, 2013; Nunes et al., 2016). Globally, $C$. quadricarinatus has been translocated to non-native areas in Australia (Doupé et al., 2004; Leland, Coughran \& Furse, 2012) and Indonesian territories (Patoka et al., 2016), and wild populations are also known from Israel (Snovsky \& Galil, 2011), Jamaica (Todd, 2005; Pienkowski et al., 2015), Mexico (Bortolini, Alvarez \& Rodriguez-Almaraz, 2007; VegaVillasante et al., 2015; Torres-Montoya et al., 2016), Puerto Rico (Williams et al., 2001), Singapore (Ahyong \& Yeo, 2007; Belle et al., 2011) and Slovenia (Jaklič \& Vrezec, 2011). This 
species has also been introduced into several other countries (where wild populations do not exist) mostly due to its use in aquaculture (Ahyong \& Yeo, 2007), but also due to being a very

popular ornamental species that is readily available in the pet trade (Belle et al., 2011; Chucholl, 2013; Patoka, Kalous \& Kopecky, 2014).

Cherax quadricarinatus was first imported into South Africa in 1988 for research on its aquaculture potential, together with other Cherax species (Van den Berg \& Schoonbee, 1991). Despite considerable interest in the aquaculture of this species in the late 1990s, its import and culture for commercial purposes has always been extremely restricted in South Africa. As a result, a farmer who failed to establish an aquaculture venture in South Africa around this time instead managed to successfully establish it in neighbouring Swaziland (de Moor, 2004). There are anecdotal reports that two batches of $C$. quadricarinatus were introduced from Australia to Swaziland, one for the abovementioned farm located near the Sand River Dam, close to the Komati River and the other to a farm near Manzini or Big Bend, in the Usutu River catchment (A Howland, 2016 - general manager of IYSIS cattle ranch, inside which the Sand River Dam is situated -, pers. comm.). As a result of escape from captivity, crayfish spread to the Sand River Dam and later via the Sand River into the Komati River (de Moor, 2002, 2004; A Howland, 2016, pers. comm.), where it was first detected in South Africa in 2002 (de Villiers, 2015). While there is no information on the outcome of the other aquaculture farm close to Manzini or Big Bend (in the Usutu River catchment), in 2012 C. quadricarinatus was detected in an outlet of Lake Nyamiti in the Ndumo Game Reserve (South Africa) (du Preez \& Smit, 2013), which eventually connects to the Usutu River.

In June 2009, the species was also reported from a small wetland in a residential area close to Richard's Bay, in KwaZulu-Natal Province, South Africa (R Jones, 2016 - Ezemvelo KZN 
89 Wildlife, pers. comm.), a distant site, not directly connected to the initial introduction sites. This

90 was probably the result of an escape, or release via the aquarium trade, although data on pet trade

91 of this species in South Africa is not available.

92 Despite these initial reports of $C$. quadricarinatus in Swaziland and South Africa, no systematic

93 survey has ever been carried out to determine their distribution, spread rate and population

94 dynamics. This is of concern because crayfish invasions have generally been shown to result in

95 strong impacts on recipient ecosystems (Lodge et al., 2012) and, given the absence of native

96 crayfish on the African continent, these impacts are likely to be even stronger, especially upon

97 native decapods, such as freshwater crabs from the genus Potamonautes (de Moor, 2002;

98 Jackson et al., 2016; Nunes et al., 2016). In this study, we assess the current distribution, rate of

99 spread and population dynamics of C. quadricarinatus populations in South Africa and

100 Swaziland. In addition, for the Komati River (initial main river of introduction), we further

101 investigate if population characteristics, such as abundance, biomass, sex ratio, body size and

102 mass vary with distance to the introduction source, since traits of invasive populations have been

103 shown to vary along invasion gradients (see review in Iacarella, Dick \& Ricciardi, 2015).

104

105

Materials \& Methods

106 Field Study Permissions

107 Permits for fieldwork in South Africa were obtained from the Mpumalanga Tourism and Parks

Agency (MPB. 5523) and Ezemvelo KZN Wildlife (OP 4428/2015). For Swaziland, permission was granted from the Mbuluzi Game Reserve and All Out Africa Foundation.

Study area 
112 The study area was mainly situated in the Inkomati, Mbuluzi and Usutu River basins, all of

113 which are international river systems running through Swaziland, South Africa and

114 Mozambique. The Inkomati basin, mainly located in the Mpumalanga Province of South Africa,

115 consists of three major sub-catchments, the Komati, the Crocodile and the Sabie-Sand (MTPA,

116 2013). The Komati sub-catchment is composed of the Komati River and its tributaries, one of

117 which is the Lomati River. The Komati River rises in South Africa, west of Carolina in

118 Mpumalanga, and flows for $480 \mathrm{~km}$ in a north-easterly direction through three countries (South

119 Africa $\rightarrow$ Swaziland $\rightarrow$ South Africa $\rightarrow$ Mozambique). The Crocodile River is the main river in

120 the Crocodile sub-catchment, originating north of Dullstroom and flowing eastwards towards its

121 confluence with the Komati River. The Sand River Dam, where C. quadricarinatus was first

122 introduced in Swaziland, is located in the Inkomati catchment (Figs. 1, 2A).

123 The main river of the Mbuluzi basin is the Mbuluzi River, which originates in the Ngwenya hills

124 in northwest Swaziland, close to the border with South Africa, and flows in an easterly direction

125 through central Swaziland into Mozambique. At times, water is transferred from the Komati

126 River basin to the Mbuluzi River basin via an intricate network of approximately $40 \mathrm{~km}$ of

127 irrigation channels (A Howland, 2016, pers. comm.; Gustafsson \& Johansson, 2006). The

128 Mlawula River, located close to the border with Mozambique, is one of its tributaries, which

129 crosses several protected areas, such as the Mbuluzi Game Reserve and the Shewula Nature

130 Reserve (Fig. 2B).

131 The Usutu River basin is bordered by the Mbuluzi and Inkomati River basins to the north and the

132 Mhlathuze coastal catchment to the south. The Usutu, Pongola and Ngwavuma are its main sub-

133 catchments. The main river of the Usutu sub-catchment is the Usutu River, which rises

134 near Amsterdam, in Mpumalanga Province, and flows in a south-easterly direction through South 
135 Africa and Swaziland (Beuster \& Clarke, 2008). It then emerges in the province of KwaZulu-

136 Natal in South Africa where, for approximately 24 kilometres, it defines the border between this

137 country and Mozambique, along the limits of the Ndumo Game Reserve. The Ndumo Game

138 Reserve, a protected area characterised by numerous pans and wetlands, is crossed by the

139 Pongola River, which rises in Northern KwaZulu-Natal, flows eastwards until the Pongolapoort

140 Dam, from where it flows north-easterly to join the Usutu River in Mozambique (Fig. 2C).

141 Taking into account the reported sighting of C. quadricarinatus close to Richard's Bay, this area

142 was also surveyed, as well as two large dams in the KwaZulu-Natal Province (Albert Falls and

143 Goedertrouw Dams), where there have been unconfirmed records of crayfish presence (L

144 Coetzer, 2015, pers. comm.) (Figs. 1, 2D).

146 Sampling sites

147 A total of 46 sampling sites in different water bodies (main rivers, tributaries, pans, wetlands and 148 dams) were surveyed between September 2015 and August 2016 (Fig. 1). Sampling sites were

149 chosen by focusing on areas with suspected presence of C. quadricarinatus, according to

150 published or grey literature and to personal communications from farmers, agriculture and

151 conservation officials. Along the Komati River, which has a large number of weirs regulating its

152 flow, nine sites were sampled, six downstream and three upstream of the initial introduction

153 point (Fig. 2A). In contrast, the Lomati River is relatively less regulated and not many sites (six)

154 could be sampled on the main river or its tributaries due to difficult access. The three sampling

155 sites on the Crocodile River were located upstream of its confluence with the Komati River and

156 within the Kruger National Park (Fig. 2A). Sites on the Mbuluzi River and its tributaries were

157 concentrated close to the Mozambican border, upstream (two) and downstream (four) of the 
158 potential point of introduction in this river (Fig. 2B). In the Usutu River, four points were 159 sampled in Swaziland and one in South Africa. Three sampling points were selected in the 160 Ndumo Game Reserve and two in the Pongola River, one upstream and one downstream of 161 Pongolapoort Dam (Fig. 2C). In the Richard's Bay area, two points, one where crayfish were 162 detected back in 2009 and one in a connected lake, were sampled (Fig. 2D). Finally, ten small 163 and large dams, most of which are primarily used to store water for agricultural irrigation, were 164 also sampled.

165 Overall, 34 sites were sampled in lotic habitats, spaced at least $2.5 \mathrm{~km}$ from each other (but 166 usually over $13 \mathrm{~km}$ ), according to where access to the rivers was possible. Survey sites in the 167 rivers ranged between 100 and $150 \mathrm{~m}$ in length, depending on accessibility of the site. Twelve 168 sites were sampled in lentic habitats. Each sampling site was surveyed at least twice (each site 21694 times, except four sites where we could not return), once in the wet season (spring/summer, 170 September-March) and once in the dry season (autumn/winter, April-August), in order to 171 confirm crayfish absences and differences in crayfish populations between seasons. The 172 exception were three sites in the Crocodile River inside Kruger National Park, an area under 173 strict jurisdiction of South African National Parks where, similarly to the four sites mentioned 174 above, we could only sample once.

176 Sampling procedure

177 At each of the sampling sites, visual observations of 5-10 minutes along the margins of the water 178 body were made on arrival at the location, in order to look for crayfish specimens or moults.

179 Subsequently, around ten (range: 3-15) CPromar collapsible crayfish/crab traps (dimensions: 61 $180 \times 46 \times 20 \mathrm{~cm}$; mesh size: $10 \mathrm{~mm}$ ), baited with approximately $100 \mathrm{~g}$ of dry dog food, were set in 
181 the evening at each site, left overnight (14-16 h) and checked the following morning. The

182 number of crayfish caught in each trap, as well as their cephalothorax length (to the nearest mm),

183 mass (to the nearest g) and sex were registered. Crayfish abundance was calculated based on

184 catch per unit effort (CPUE), per sampling session. Due to restrictions imposed by SANParks,

185 traps could not be set in the Crocodile River, where instead electrofishing was conducted by

186 wading for approximately 40 minutes per site, using a handheld SAMUS 725MP, with a $10 \mathrm{~mm}$

187 mesh scoop net.

188

189

Data analysis

190

A chi-square goodness-of-fit test was used to test whether overall sex ratio, or per site and per

191 season, was significantly different than the common sex ratio of 1:1 (e.g. Bortolini, Alvarez \&

Rodriguez-Almaraz, 2007; Belle et al., 2011). For the Komati River, we also investigated a

possible relationship between each site's distance from the crayfish source of introduction

194

195

196

197

198

199

200

201

202 (measured, in km, using Google Earth, downstream from the site of initial crayfish introduction and following the river's natural course) and crayfish catch per unit effort (abundance and biomass), sex ratio, size and mass. This was determined using Pearson's correlation coefficient or, in case the assumptions of normality or homogeneity of variances were not met, the nonparametric Spearman rank correlation. The level of significance for all statistical tests performed was $p<0.05$.

\section{Results}

\section{Presence/absence}


203 Cherax quadricarinatus was detected in 22 out of the 46 sampling sites surveyed (Figs. 1, 2,

204 Tables 1, S1). All sampling sites located on the Komati and Lomati rivers in South Africa had

205 crayfish present, but no crayfish were detected in the upstream and more elevated sampling sites

206 on both rivers in Swaziland. Crayfish were also found in the Mbuluzi River, but only in sampling

207 sites downstream of the potential introduction point (interbasin transfer point between the

208 Inkomati and Mbuluzi basins) in this river (Fig. 2B). Both sites on the Mlawula River, a tributary

209 of the Mbuluzi River, also yielded crayfish. On the Usutu River, three sites close to Big Bend

210 had crayfish, but crayfish were not caught further upstream in Swaziland, or downstream in

211 Ndumo Game Reserve (Figure 2C). Crayfish were also found in six out of the 12 sampled lentic

212 habitats. However, they were not detected in the Crocodile and Pongola rivers, Ndumo Game

213 Reserve and the Richard's Bay area (Fig. 2, Table S1).

215 Abundance

216 A total of 577 crayfish were caught during the wet season (383 males and 194 females), with a

217 maximum of 63 individuals in a single trap (at site D01), whereas only 267 crayfish were caught

218 in the dry season (149 males and 118 females). The maximum mass that a crayfish attained was

$219250 \mathrm{~g}$, for an individual caught at site K06 (Table 1). In the Komati River, average crayfish

220 abundances were quite high, ranging from 0.4 to 9.4 individuals.trap.night ${ }^{-1}$ per site in the wet

221 season and 1.0 to 7.0 individuals.trap.night ${ }^{-1}$ in the dry season. High abundances were also found

222 in dams (0.1-15.3 individuals.trap.night $\left.{ }^{-1}\right)$, especially during the wet season. Abundances were

223 lower in the Mbuluzi (1.0-4.5 individuals.trap.night $\left.{ }^{-1}\right)$ and Mlawula rivers (0-4.0

224 individuals.trap.night ${ }^{-1}$ ) and much lower in the Lomati and Usutu rivers ranging, respectively,

225 from 0-0.7 individuals.trap.night ${ }^{-1}$ and 0.1-0.8 individuals.trap.night ${ }^{-1}$ (Table 1). Average biomass 
226 was higher in the dry than in the wet season in the Komati (47.4 g.trap.night ${ }^{-1}$ for dry season and

22735.7 g.trap.night ${ }^{-1}$ for wet season), Lomati (26.1 g.trap.night ${ }^{-1}$ for dry season and 7.4 g.trap.night

$228{ }^{1}$ for wet season) and Mbuluzi rivers (27.8 g.trap.night ${ }^{-1}$ for dry season and 22.0 g.trap.night ${ }^{-1}$ for

229 wet season). On the contrary, average biomass was higher in the wet than the dry season in the

230 Mlawula River (15.5 g.trap.night ${ }^{-1}$ for wet season and 5.4 g.trap.night ${ }^{-1}$ for dry season), Usutu

231 River (10.9 g.trap.night ${ }^{-1}$ for wet season and 5.2 g.trap.night ${ }^{-1}$ for dry season) and in dams (34.8

232 g.trap.night ${ }^{-1}$ for wet season and 25.6 g.trap.night ${ }^{-1}$ for dry season) (Table 1).

233

234 Size classes

235 Specimens of C. quadricarinatus varied widely in size, with cephalothorax lengths ranging from 23620 to $114 \mathrm{~mm}$, and individuals between 40 and $70 \mathrm{~mm}$ being by far the most numerous and 237 representing $73.66 \%$ of all measured crayfish. Length-frequency graphs demonstrated the 238 existence of multiple cohorts in the Komati, Mbuluzi, Mlawula and Usutu rivers, and also in 239 irrigation dams. This did not seem to be the case for the Lomati River, where only very few size 240 classes were present (Figs. 3A, B).

241 Ovigerous females, or females carrying newly hatched crayfish (average size $63.8 \mathrm{~mm}$, average 242 mass $58.7 \mathrm{~g}$ ) were found in October and December 2015, at five different sampling sites, three 243 on the Komati River (K01, K02 and K03) and two in dams (D01 and D02) (Table S2). The 244 number of eggs ranged from 281 to 539 and the number of newly hatched crayfish ranged from 24518 to 20 (many probably detached while in the traps).

247 Sex ratio 
248 In the wet season, the overall sex ratio (all sampling sites together) was significantly different

249 from the expected sex ratio of $1: 1\left(\chi^{2}=58.856, p<0.001\right)$, with males outnumbering females,

250 while this was marginally non-significant in the dry season $\left(\chi^{2}=3.626, p=0.057\right)$. Looking at

251 specific areas, in the wet season, males were significantly more numerous than females in the

252 Komati $\left(\chi^{2}=8.022, p=0.005\right)$ and Mlawula rivers $\left(\chi^{2}=3.930, p=0.047\right)$, as well as in dams $\left(\chi^{2}=\right.$

$25345.478, p<0.001)$, but not in the Mbuluzi $\left(\chi^{2}=3.457, p=0.063\right)$ or the Usutu rivers $\left(\chi^{2}=1.600\right.$,

$254 p=0.206)$. In the dry season, sex ratios were not significantly different to the expected 1: 1

255 proportion ( $p \geq 0.05$ in all cases). However, if we consider sampling sites individually, sex ratio

256 was not significantly different from the 1: 1 proportion for most of them ( $p>0.05$ for most sites),

257 except for sites K03 $\left(\chi^{2}=13.787, p<0.001\right)$, D01 $\left(\chi^{2}=45.026, p<0.001\right)$ and D05 $\left(\chi^{2}=4.378, p=\right.$

258 0.036) in the wet season and D01 in the dry season $\left(\chi^{2}=8.257, p=0.004\right)$ (Table 1$)$.

259

260 Spread rate

261 In the Komati River, crayfish were found at a maximum distance of $112 \mathrm{~km}$ downstream of the

262 point of introduction, indicating a minimum downstream spread rate of $8 \mathrm{~km}^{\text {year-1 }}$ (using 2001

263 as the approximate year of first introduction). In the Lomati River, they were detected $93 \mathrm{~km}$

264 from the source of introduction, approximately $33 \mathrm{~km}$ upstream from the confluence with the

265 Komati River. This indicates a total spread rate of $6.6 \mathrm{~km} . \mathrm{year}^{-1}$ and, using the calculated

266 average spread rate of $8 \mathrm{~km}$.year ${ }^{-1}$ downstream until the confluence with the Komati River, an

267 upstream spread rate of 4.7 km.year ${ }^{-1}$.

268

269

Variation with distance to source of introduction 
270 No significant correlations were found between abundance, biomass or sex ratio of $C$.

271 quadricarinatus during both wet and dry seasons, and distance to crayfish introduction source in

272 the Komati River (for all correlations, $p>0.05$ ). However, size and mass of both females and

273 males was significantly correlated with distance to the source of crayfish introduction.

274 Interestingly, a significant positive correlation was found between these variables for females in

275 the wet season $(r=0.344, N=69, P=0.004$ for size and $r=0.438, N=71, P<0.001$ for mass),

276 while during the dry season these correlations were negative $(r=-0.686, N=63, P<0.001$ for size

277 and $r=-0.641, N=63, P<0.001$ for mass) (Fig. 4A). For males, the relationship was always

278 negative, independent of season, but only statistically significant in the dry season $(r=-0.440, N=$

$27966, P<0.001$ for size and $r=-0.505, N=66, P<0.001$ for mass) (Fig. 4B).

Discussion

282 In this study we confirmed the presence of established and widespread populations of $C$. quadricarinatus in South Africa and Swaziland. Based on the evidence that populations have spread and are reproducing at multiple localities as far as $115 \mathrm{~km}$ from the point of introduction, this species can be considered as fully invasive (category E) in these countries, according to Blackburn et al. (2011). We also show how populations of this species have expanded in South Africa and Swaziland since they were first detected in 2002, being now present in at least three large rivers (Komati, Mbuluzi and Usutu), two tributaries (Lomati and Mlawula rivers), as well as in several irrigation dams. Crayfish populations were found to be established (presence of multiple cohorts and reproduction) at most sampling sites, the main exception being the Lomati River, where very few individuals were sampled. 
292 Although C. quadricarinatus were found to have dispersed upstream in two different tributaries

293 (Lomati and Mlawula rivers), they were not detected upstream of the known point of

294 introduction in the Komati River and in upstream sections of the Lomati River. This might be

295 related with the large increase in elevation in these sampling points (274-433 $\mathrm{m}$ a.s.1) and/or

296 potential lower water temperatures. In the Lomati River, the Driekoppies Dam, located just by

297 the border with Swaziland, and where no crayfish were found (or upstream of it), might also act

298 as a dispersal barrier. Crayfish were also not detected in the Crocodile River; however, some

299 specimens were recently detected approximately $10.7 \mathrm{~km}$ upstream of the furthest point sampled

300 in this study (A Hoffman, T Zengeya, 2016, pers. obs.). The fact that no individuals were

301 sampled from the Ndumo Game Reserve was surprising and suggests small population sizes in

302 the area, probably a result of an extended drought period.

303 Crayfish were not found in sites near Richard's Bay, indicating that the record from 2009 was

304 indeed probably the result of an isolated introduction event, through release by aquarists or

305 escape from an ornamental pond. This would not be surprising, as several crayfish species

306 including C. quadricarinatus are available for sale in South Africa, either via online sources or in

307 pet shops around the country (AL Nunes, 2016, pers. obs.). The anecdotal reports of crayfish at

308 Albert Falls Dam and Goedertrouw Dam could not be confirmed during the current surveys.

309 However, it is important to note that, given the extensive size of these dams, it is extremely

310 difficult to confirm crayfish absence, especially without an intensive and focused sampling,

311 targeted specifically for these type of habitats.

312 Relative abundances of C. quadricarinatus in the Komati River (average 3.3 indv.trap.night $^{-1}$;

313 maximum 9.4 indv.trap.night ${ }^{-1}$ ) and in irrigation dams (average 3.7 indv.trap.night ${ }^{-1}$; maximum

31415.3 indv.trap.night $^{-1}$ ) were considerably higher than the ones found in other invasive 
315 populations of this species in Zimbabwe (maximum of 4.0 indv.trap.night ${ }^{-1}$; Marufu, Phiri \&

316 Nhiwatiwa, 2014) and Slovenia (0.09 indv.trap.night ${ }^{-1}$; Jaklič \& Vrezec, 2011), reflecting how

317 well the species has adapted in this region. In the Lomati River, crayfish were less abundant

318 (average 0.2 indv.trap.night $^{-1}$ ), probably reflecting either a more recent invasion or a less suitable

319 habitat (Hudina et al., 2012). The Lomati River is less regulated than the Komati River,

320 containing fewer gauging weirs and consequently having higher flow velocity (A Hoffman, A

321 Nunes, 2016, pers. obs.).

322 The observed average size range of C. quadricarinatus collected in the various sampling sites

323 (cephalothorax length: 20-98.2 mm) was in the range of values reported for this species other

324 invasive populations (Bortolini, Alvarez \& Rodriguez-Almaraz, 2007; Jaklič \& Vrezec 2011;

325 Marufu, Phiri \& Nhiwatiwa, 2014). The sex ratio at individual sampling sites was generally not

326 significantly different from the commonly found 1: 1 ratio (e.g. Bortolini, Alvarez \& Rodriguez-

327 Almaraz, 2007; Belle et al., 2011). However, it is interesting that the overall sex ratio (all

328 sampling sites) in the wet season was significantly different from 1: 1, with males outnumbering

329 females. This probably reflects reduced capture vulnerability of females during the reproduction

330 season, when berried females are less active (Masser \& Rouse, 1997).

331 The species exhibited potential to disperse both downstream the different initial invasion points

332 and upstream of two different tributaries. In the Inkomati basin, downstream and upstream

333 spread occurred at a rate of 8 and $4.7 \mathrm{~km} \cdot \mathrm{year}^{-1}$, respectively. However, the downstream rate

334 might be higher, considering the high likelihood that the species has already spread further

335 downstream the Komati River into the Mozambican side (which could not be sampled in this

336 study). Cherax quadricarinatus most likely reached the Mbuluzi River basin via irrigation canals

337 that act as an interbasin water transfer between the Mbuluzi and Inkomati basins (similarly to 
338 that facilitating the spread of an alien loricariid catfish in the KwaZulu-Natal province; Jones et

339 al., 2013). While the date of introduction is uncertain, crayfish were observed for the first time in

3402009 at the Pequenos Libombos Dam in southern Mozambique (I Nerantzoulis, 2016, pers.

341 comm.), and were recorded as established in 2011 (Fig. 2B; Chivambo, Nerantzoulis \&

342 Mussagy, 2013). Assuming this was the result of natural spread, and not of an exceptional

343 translocation event, this demonstrates that in eight years, and in a downstream direction, the

344 species covered $40 \mathrm{~km}$ of channels between the Mbuluzi and Inkomati basins, plus $76.8 \mathrm{~km}$ in

345 the Mbuluzi River until the Pequenos Libombos Dam, indicating a potential spread rate of 14.6

346 km.year-1.

347 Down and upstream dispersal have been observed for other invasive crayfish species, ranging

348 from 1.8 to $24.4 \mathrm{~km}$ year $^{-1}$ (downstream) and 0.35 to $4 \mathrm{~km} . \mathrm{year}^{-1}$ (upstream) for Pacifastacus

349 leniusculus in different European countries (Bubb, Thom \& Lucas, 2005; Hudina et al., 2009;

350 Weinländer \& Füreder, 2009; Bernardo et al., 2011), 0.5 to $3.10 \mathrm{~km}$ year-1 (upstream) for $P$.

351 clarkii (Bernardo et al., 2011; Ellis et al., 2012), and 12 to 84 km.year-1 (downstream) and 2.5

352 km.year-1 (upstream) for Orconectes limosus in Eastern Europe (Hudina et al., 2009). This

353 indicates that the first estimates of dispersal rates for C. quadricarinatus, especially for upstream

354 movements, are high, once again suggesting a high invasion potential of the species in the study

355 area. Furthermore, irrigation dams, where crayfish populations seem to become very abundant,

356 might act as secondary sources of crayfish invasions or as stepping stones for range expansion

357 through irrigation channels or over land, facilitating subsequent establishment in new irrigations

358 dams, rivers or tributaries.

359 In the Komati River, which has been colonised for the longest time, crayfish were generally

360 larger and heavier close to the initial introduction point, with sizes decreasing as distance to the 
361 invasion source increased. A similar pattern has been observed for round goby invasions in

362 Canada (Ray \& Corkum, 2001; Brownscombe \& Fox, 2012) and the same tendency found for

363 signal crayfish in Croatia (Hudina et al., 2012), suggesting that juveniles may disperse more

364 actively and rapidly than adults, likely due to high intraspecific competition. In the case of

365 females, this might also indicate a strategy that allocates resources to favour reproduction with

366 increased offspring closer to the source, as egg number is a function of female size (Jones, 1990).

367 It is important to note that as distance to the invasion source increases in the Komati River,

368 elevation decreases. This means that the pattern found may also indicate that larger and heavier

369 individuals are more common in more elevated areas.

370 However, the opposite pattern was observed for females during the wet season, with smaller

371 females found near the introduction point and larger ones further downstream. Given that sexual

372 maturity is generally reached when animals attain around 50 to $60 \mathrm{~g}$ (Jones, 1990),

373 corresponding to approximately 55 to $65 \mathrm{~mm}$ cephalothorax length in this study, this may

374 indicate that mature females might be reproducing at different times of the year along the

375 invasion gradient. In sites further away from the source females are spawning in October-

376 December (and perhaps repeatedly), while reproduction might be taking place at a different time

377 of the year in longer established populations. Nevertheless, taking into account that large berried

378 females are usually less active and, therefore, less susceptible to capture (Masser \& Rouse,

379 1997), differences in reproductive activity might be affecting sampling efficiency. Still, the

380 possibility that reproductive behaviour might differ along the invasion gradient warrants further

381 investigation, especially considering that $C$. quadricarinatus has a natural reproductive season

382 throughout spring and summer, with spawning occurring more than once from October to March

383 (Jones, 1990; Masser \& Rouse, 1997). Alternatively, the pattern found might also suggest that 
384 large females closer to the invasion front are more active and disperse during the wet season,

385 which might contribute to further range expansion (Brownscombe \& Fox, 2012).

386 Although current legislation prohibits the importation, release and movement of $C$.

387 quadricarinatus in South Africa (RSA, 2016), the lack of resources (both manpower and

388 financial) makes it extremely challenging to enforce these regulations. Furthermore, taking into

389 account the accidental escape of $C$. quadricarinatus from an aquaculture farm in Swaziland and 390 consequent spread to South Africa and Mozambique, this study reinforces the importance of

391 putting international agreements regarding invasive species into practice. The SADC Protocol on

392 Fisheries for example, prohibits the introduction of alien species into aquatic ecosystems shared

393 by two states, unless all the affected states agree to the introduction (de Moor, 2004). Clearly,

394 there is a need to strengthen and better coordinate the enforcement and effectiveness of existing

395 protocols between neighbouring countries in Africa, in what concerns introduction and spread of

396 invasive species. Taking into account that, once established, invasive crayfish populations are

397 usually impossible to eradicate, transnational cooperation should also be taken into account

398 regarding possible management actions (e.g. mechanical, physical, chemical and/or autocidal

399 methods; reviewed in Gherardi et al., 2011) to contain or hinder the spread of C. quadricarinatus

400 in these international river systems. These actions would need to be implemented by all countries

401 involved (South Africa, Swaziland and Mozambique), in order for the efforts of one country to

402 not be jeopardised by the other non-complying countries.

\section{Conclusions}

404 This study shows that populations of C. quadricarinatus are now established and spreading in

405 South Africa and Swaziland. While the environmental impact of C. quadricarinatus in newly

406 invaded habitats has yet to be determined, local communities in South Africa have already 
407 started harvesting it (Coetzee et al., 2015), increasing the risk of translocations for commercial

408 reasons. The possible introduction of this species into new catchments in Africa is a matter of

409 extreme concern, especially given the high speed at which the species has been expanding and its

410 potential impacts on native biota, such as disease introductions, competitive interactions with

411 native freshwater crustaceans or habitat modifications (de Moor, 2002; Nunes et al., 2016).

412 However, as no formal research has been done on the impacts of C. quadricarinatus invasive

413 populations in any part of the world, the species would be classified as 'Data Deficient' (current

414 information insufficient to assess level of impact) according to Blackburn's et al. (2014)

415 environmental impact classification for alien taxa. This calls for an immediate assessment of

416 potential impacts of this species on native freshwater ecosystems in Africa.

417

418 Acknowledgments

419 We are greatly indebted to Len Coetzer for showing us various sampling sites in South Africa 420 and for providing us the contact details of numerous farmers and researchers in the area. We also

421 thank Vhutali Nelwamondo, Jonathan Vervaeke and Rheul Lombard for their invaluable help

422 during field work. We are grateful to the South African National Parks (SanParks), in the person

423 of Robin Petersen, for permission to sample the Crocodile River inside Kruger National Park.

424 We are grateful to Prof. CN Magagula for her essential help in contacting permitting authorities

425 in Swaziland and to Morgan Vance at the Savannah Research Centre for receiving us so well in

426 Swaziland. ALN, OLFW and GJM thank the National Research Foundation and the DST-NRF

427 Centre of Excellence for Invasion Biology for their continued support.

428

429 References 
430 Ahyong ST, Yeo DCJ. 2007. Feral populations of the Australian red-claw crayfish (Cherax

431 quadricarinatus von Martens) in water supply catchments of Singapore. Biological Invasions $4329: 943-946$.

433 Belle CC, Wong JQH, Yeo DCJ, Tan SH, Tan HH, Clews E, Todd PA. 2011. Ornamental trade 434 as a pathway for Australian redclaw crayfish introduction and establishment. Aquatic Biology $435 \quad 12: 69-79$.

436 Bernardo JM, Costa AM, Bruxelas S, Teixeira A. 2011. Dispersal and coexistence of two non437 native crayfish species (Pacifastacus leniusculus and Procambarus clarkii) in NE Portugal 438 over a 10-year period. Knowledge and Management of Aquatic Ecosystems 401:28.

439 Beuster J, Clarke FA. 2008. Joint Maputo River Basin Water Resources Study - Moçambique, 440 Swaziland and South Africa. Tripartite Permanent Technical Committee (TPTC): Republic of 441 Moçambique, Republic of South Africa and Kingdom of Swaziland.

442 Blackburn TM, Essl F, Evans T, Hulme PE, Jeschke JM, Kühn I, Kumschick S, Pyšek P, 443 Rabitsch W, Ricciardi A, Richardson DM, Sendek A, Vilà M, Wilson JRU, Winter M, 444 Genovesi P, Bacher S. 2014. A unified classification of alien species based on the magnitude 445 of their environmental impacts. PLOS Biology 12:e1001850.

Blackburn TM, Pyšek P, Bacher S, Carlton JT, Duncan RP, Jarošík V, Wilson JRU, Richardson DM. 2011. A proposed unified framework for biological invasions. Trends in Ecology and Evolution 26:333-339.

450

Bortolini JL, Alvarez F, Rodriguez-Almaraz G. 2007. On the presence of the Australian redclaw crayfish, Cherax quadricarinatus, in Mexico. Biological Invasions 9:615-620. crayfish: A global overview. CRC Press, Boca Raton, 583-593. 
453 Brownscombe JW, Fox MG. 2012. Range expansion dynamics of the invasive round goby

454 (Neogobius melanostomus) in a river system. Aquatic Ecology 46:175-189.

455

456

457

458

459

460

461

462

463

464

465

466

467

468

469

470

471

472

473

474

475

Bubb DH, Thom TJ, Lucas MC. 2005. The within catchment invasion of the non-indigenous signal crayfish Pacifastacus leniusculus (Dana), in upland rivers. Bulletin Français de la Pêche et de la Pisciculture 376-377:665-673.

Chivambo S, Nerantzoulis I, Mussagy A. 2013. O lagostim invasor na Albufeira dos Pequenos Libombos, Maputo, Moçambique: avaliação das relações tróficas. 3as Jornadas Científicas de Docentes e Investigadores da Faculdade de Ciências, Maputo, Mozambique.

Chucholl C. 2013. Invaders for sale: trade and determinants of introduction of ornamental freshwater crayfish. Biological Invasions 15:125-141.

Coetzee HC, Nell W, Van Eeden ES, De Crom EP. 2015. Artisanal fisheries in the Ndumo area of the Lower Phongolo River Floodplain, South Africa. Koedoe 57:1248(1-6).

de Moor I. 2002. Potential impacts of alien freshwater crayfish in South Africa. African Journal of Aquatic Sciences 27:125-139.

de Moor I. 2004. Protocols for moving germplasm among countries in Africa. In: Gupta MV, Bartley DM, Acosta BO, eds. Use of genetically improved and alien species for aquaculture and conservation of aquatic biodiversity in Africa. WorldFish Center Conference Proceedings 68, Penang, Malaysia, 77-92.

de Villiers M. 2015. Freshwater crayfish found in Komati River. Lowvelder. Available at http://lowvelder.co.za/279853/crayfish-web/ (accessed 8 July 2015).

Doupé RG, Morgan DL, Gill HS, Rowland AJ. 2004. Introduction of redclaw crayfish Cherax quadricarinatus (von Martens) to Lake Kununurra, Ord River, Western Australia: prospects for a 'yabby' in the Kimberley. Journal of the Royal Society of Western Australia 87:187-191. 
476 Du Preez L, Smit N. 2013. Double blow: Alien crayfish infected with invasive temnocephalan in 477 South African waters. South African Journal of Science 109:9/10(1-4).

478 Ellis A, Jackson MC, Jennings I, England J, Phillips R. 2012. Present distribution and future 479 spread of Louisiana red swamp crayfish Procambarus clarkii (Crustacea, Decapoda, Astacida, 480 Cambaridae) in Britain: Implications for conservation of native species and habitats.

$481 \quad$ Knowledge and Management of Aquatic Ecosystems 406:05.

482 Foster J, Harper D. 2006. Status of the alien Louisianan red swamp crayfish Procambarus 483 clarkii Girard and the native African freshwater crab Potamonautes loveni in rivers of the 484 Lake Naivasha catchment, Kenya. Freshwater Crayfish 15:189-194.

Gherardi F, Aquiloni L, Diéguez-Uribeondo, Tricarico E. 2011. Managing invasive crayfish: is 486 there a hope? Aquatic Sciences 73:185-200.

487 Gustafsson A, Johansson M. 2006. An investigation of nutrient levels along the Mbuluzi River 488 A background for sustainable water resources management. Master of Science Thesis, Lund $489 \quad$ University, Sweden.

Hudina S, Faller M, Lucić A, Klobučar G, Maguire I. 2009. Distribution and dispersal of two 491 invasive crayfish species in the Drava River basin, Croatia. Knowledge and Management of Aquatic Ecosystems 394-395:09.

Hudina S, Hock K, Žganec K, Lucić A. 2012. Changes in population characteristics and structure 494 of the signal crayfish at the edge of its invasive range in a European river. Annales de Limnologie- International Journal of Limnology 48:3-11. an invasive freshwater crustacean. Diversity and Distributions 21:803-812. 
498 Jackson MC, Gery J, Miller K, Britton JR, Donohue I. 2016. Dietary niche constriction when

499 invaders meet natives: Evidence from freshwater decapods. Journal of Animal Ecology

$500 \quad 85: 1098-1107$.

501 Jaklič M, Vrezec A. 2011. The first tropical alien crayfish species in European waters: the

502 redclaw Cherax quadricarinatus (Von Martens, 1868) (Decapoda, Parastacidae). Crustaceana $503 \quad 84(5-6): 651-665$.

504 Jones CM. 1990. The biology and aquaculture potential of Cherax quadricarinatus. Queensland 505 Department of Primary Industries and Fisheries. Final Report for Project No. QDPI/8860.

506 Queensland, Australia.

507 Jones RW, Weyl OLF, Swartz ER, Hill MP. 2013. Using a unified invasion framework to 508 characterize Africa's first loricariid catfish invasion. Biological Invasions 15:2139-2145.

509 Leland JC, Coughran J, Furse JM. 2012. Further translocation of the Redclaw, Cherax

510 quadricarinatus (Decapoda: Parastacidae), to Lake Ainsworth in northeastern New South $511 \quad$ Wales, Australia. Crustacean Research 7:1-4.

512 Lodge DM, Deines A, Gherardi F, Yeo DCJ, Arcella T, Baldridge AK, Barnes MA, Chadderton 513 WL, Feder JL, Gantz CA, Howard GW, Jerde CL, Peters BW, Peters JA, Sargent LW, Turner

514 CR, Wittmann ME, Zeng Y. 2012. Global introductions of crayfishes: evaluating the impact 515 of species invasions on ecosystem services. Annual Review of Ecology, Evolution and $516 \quad$ Systematics 43:449-472.

517 Lowery RS, Mendes AJ. 1977. Procambarus clarkii in Lake Naivasha, Kenya, and its effects on 518 established and potential fisheries. Aquaculture 11:111-121. 
519 Marufu LT, Phiri C, Nhiwatiwa T. 2014. Invasive Australian crayfish Cherax quadricarinatus in

520 the Sanyati Basin of Lake Kariba: a preliminary survey. African Journal of Aquatic Sciences

$521 \quad 39: 233-236$.

522 Masser MP, Rouse DB. 1997. Australian redclaw crayfish. SRAC Publication No. 244:1-8.

523 Mikkola H. 1996. Alien freshwater crustacean and indigenous mollusc species with aquaculture

524 potential in Eastern and Southern Africa. South African Journal of Science 22:90-99.

525 MTPA, Mpumalanga Tourism and Parks Agency. 2013. Ecostatus of the Crocodile River

526 Catchment, Inkomati River System. Report submitted to the Inkomati Catchment

527 Management Agency.

528 Nunes AL, Douthwaite RJ, Tyser B, Measey GJ, Weyl OLF. 2016. Invasive crayfish threaten

529 Okavango Delta. Frontiers in Ecology and the Environment 14:237-238.

530 Nunes AL, Hoffman AC, Zengeya TA, Measey GJ, Weyl OLF. 2017. Red swamp crayfish,

531 Procambarus clarkii, found in South Africa 22 years after attempted eradication. Aquatic

532 Conservation: Marine and Freshwater Ecosystems.

533 Patoka J, Kalous L, Kopecky. 2014. Risk assessment of the crayfish pet trade based on data from

534 the Czech Republic. Biological Invasions 16:2489-2494.

535 Patoka J, Wardiatno Y, Yonvitner, Kuř́íková P, Petrtýl M, Kalous L. 2016. Cherax

536 quadricarinatus (von Martens) has invaded Indonesian territory west of the Wallace Line:

537 evidences from Java. Knowledge and Management of Aquatic Ecosystems 417:39.

538 Pienkowski T, Williams S, McLaren K, Wilson B, Hockley N. 2015. Alien invasions and

539 livelihoods: Economic benefits of invasive Australian red claw crayfish in Jamaica.

$540 \quad$ Ecological Economics 112:68-77. 
541 Ray WJ, Corkum LD. 2001. Habitat and site affinity of the round goby. Journal of Great Lakes

$542 \quad$ Research 27:329-334.

543 RSA, Republic of South Africa. 2016. National Environmental Management: 395 Biodiversity

544 Act 396 (10/2004): Alien and Invasive Species List. Government Printer, Pretoria.

545 Schoonbee HJ. 1993. Occurrence of the red swamp crawfish Procambarus clarkii (Crustacea:

546 Cambaridae) in the Crocodile River at Dullstroom, Transvaal. Water SA 19:163-166.

547 Snovsky G, Galil BS. 2011. The Australian redclaw crayfish Cherax quadricarinatus (von

548 Martens, 1868) (Crustacea: Decapoda: Parastactidae) in the Sea of Galilee, Israel. Aquatic

$549 \quad$ Invasions 6:S29-S31.

550 Todd S. 2005. The introduced red claw crayfish in Jamaica. Jamaica Clearing-House

551 Mechanism, Institute of Jamaica, Jamaica. Available at

552 http://jamaicachm.org.jm/PDF/April2005.pdf (accessed 13 October 2016).

553 Torres-Montoya EH, Salomón-Soto VM, Bucio-Pacheco M, Torres-Avendaño JI, López-Ruiz

554 M, Sánchez-Gonzáles S, Castillo-Ureta H. 2016. First record of wild populations of Cherax

555 quadricarinatus (Decapoda: Parastacidae) in Sinaloa, Mexico. Revista Mexicana de

556 Biodiversidad 87:258-260.

557 van den Berg RA, Schoonbee HJ. 1991. Freshwater crayfish species of Cherax (Decapoda:

558 Parastacidae) under investigation in the Zoology Department of the Rand Afrikaans

559 University - A preliminary report. Johannesburg, 177-185.

560 van Rooyen L. 2013. Feral freshwater crayfish: ideal food. Farmer's Weekly. Available at

561 http://www.farmersweekly.co.za/agri-technology/farming-for-tomorrow/feral-freshwater-

562 crayfish-ideal-food/ (accessed 17 February 2017). 
563 Vega-Villasante F, Ávalos-Aguilar JJ, Nolasco-Soria H, Vargas-Ceballos MA, Bortolini-Rosales

564 JL, Chong-Carrillo O, Ruiz-Núñez MF, Morales-Hernández JC. 2015. Wild populations of

565 the invasive Australian red claw crayfish Cherax quadricarinatus (Crustacea, Decapoda) near

566 the northern coast of Jalisco, Mexico: a new fishing and profitable resource. Latin American

567 Journal of Aquatic Research 43:781-785.

568 Weinländer M, Füreder L. 2009. The continuing spread of Pacifastacus leniusculus in Carinthia

569 (Austria). Knowledge and Management of Aquatic Ecosystems 394-395:17.

570 Williams EW Jr, Bunkley-Williams L, Lilyestrom CG, Ortiz-Corps EA. 2001. A review of

571 recent introductions of aquatic invertebrates in Puerto Rico and implications for the

572 management of nonindigenous species. Caribbean Journal of Science 37:246-251. 
Figure 1

Study area in South Africa and Swaziland.

General overview of the study area showing the 46 sampling sites used in this study. Full circles and triangles respectively represent river and dam sites where crayfish was found, empty circles and triangles represent river and dam sites where crayfish was not detected. Black stars indicate sites where crayfish presence has been previously reported and red stars represent the approximate potential points of first introduction.

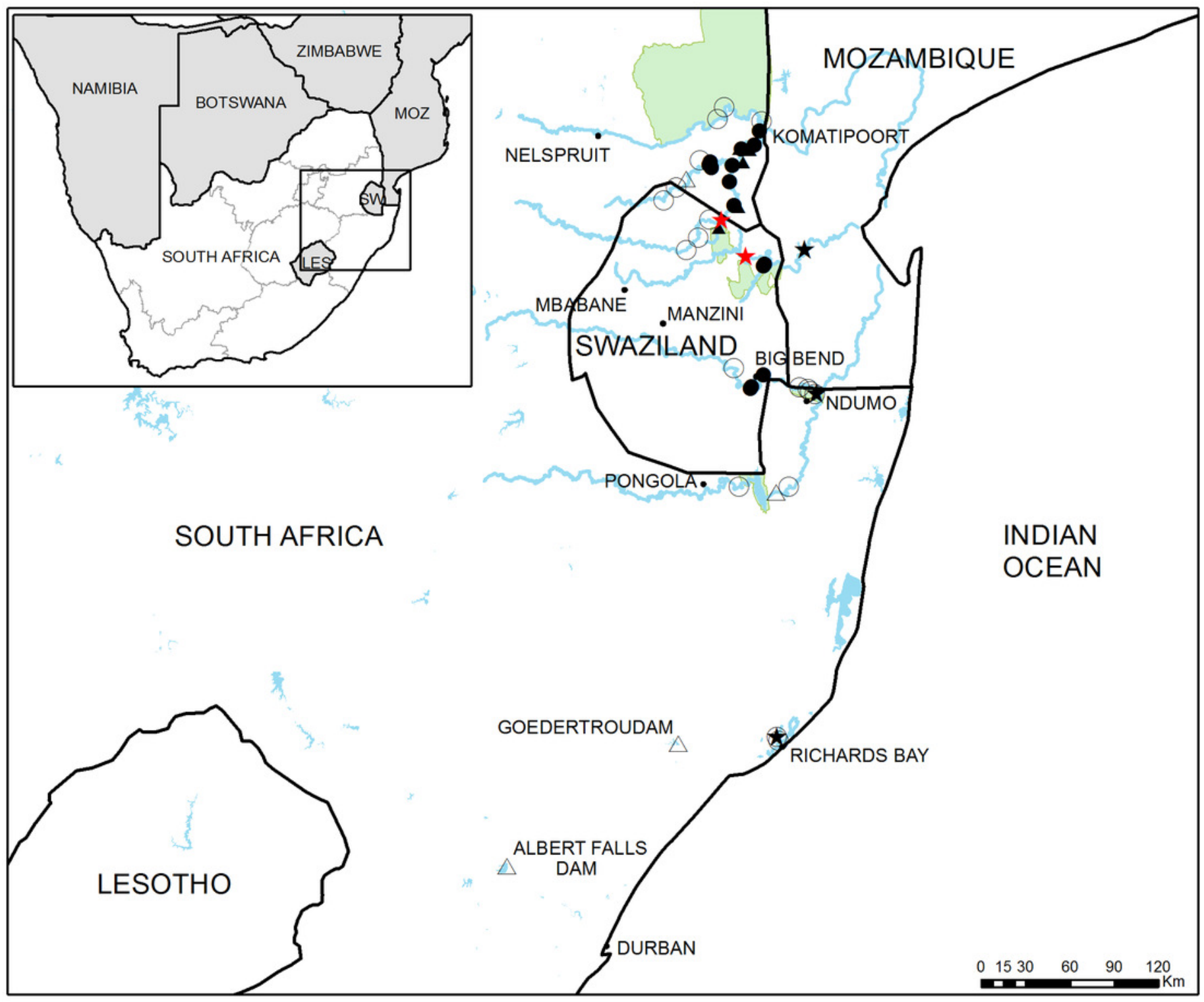




\section{Figure 2}

Detailed view of the four main study areas, with the 46 sampling sites used in this study.

(A) The Inkomati, (B) Mbuluzi and (C) Usutu river basins and (D) Richard's Bay area. The approximate point of first introduction of $\mathrm{C}$. quadricarinatus in the Komati River and the potential point of introduction in the Mbuluzi River are indicated with red stars. Full circles and triangles respectively represent river and dam sites where crayfish was found, empty circles and triangles represent river and dam sites where crayfish was not detected. Black stars indicate sites where crayfish presence has been previously reported.
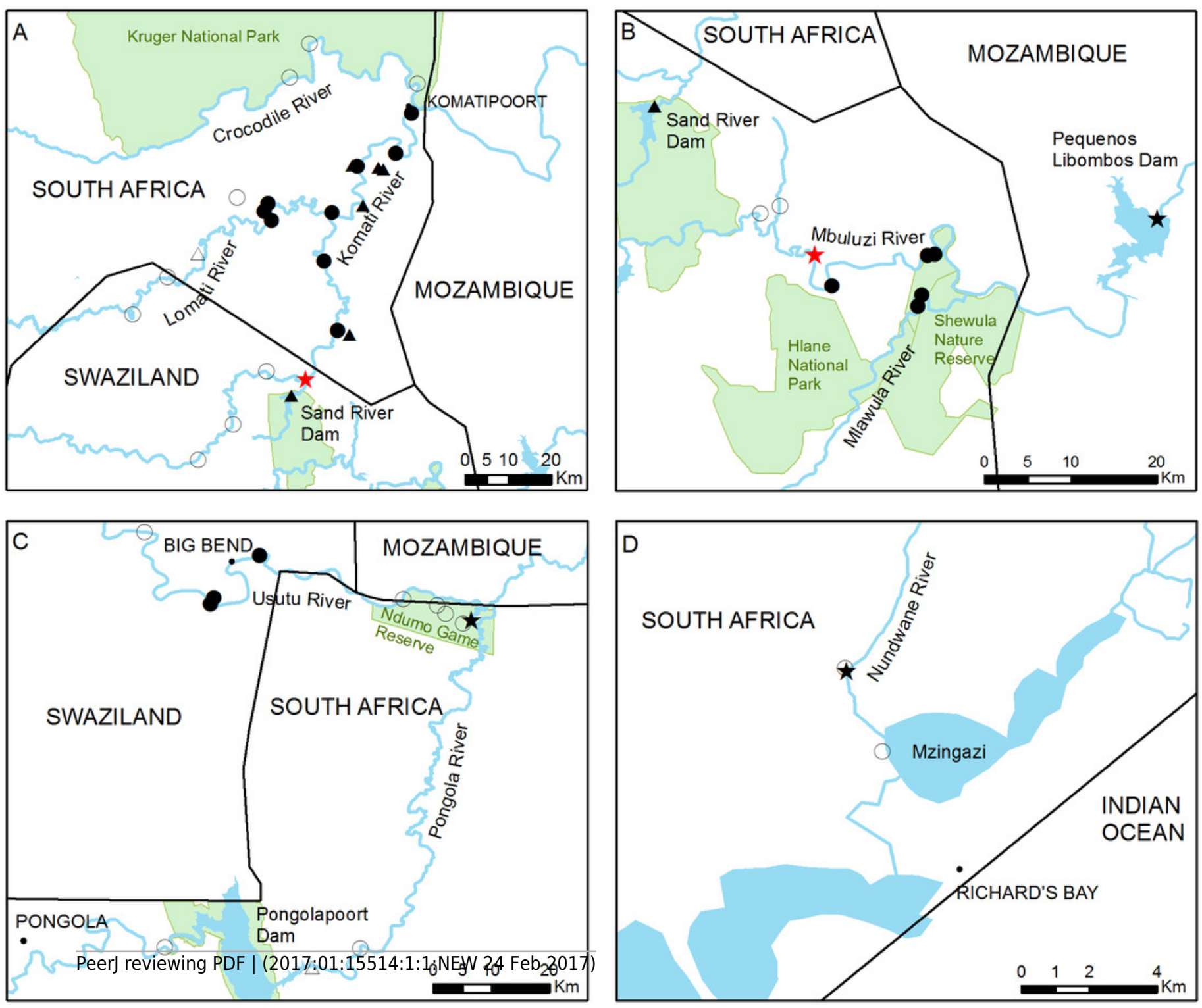
Figure 3

Length-frequency distributions of $\mathrm{C}$. quadricarinatus in different locations of the Komati, Mbuluzi, Mlawula, Usutu and Lomati rivers and in irrigation dams.

(A) Wet season and (B) Dry season.

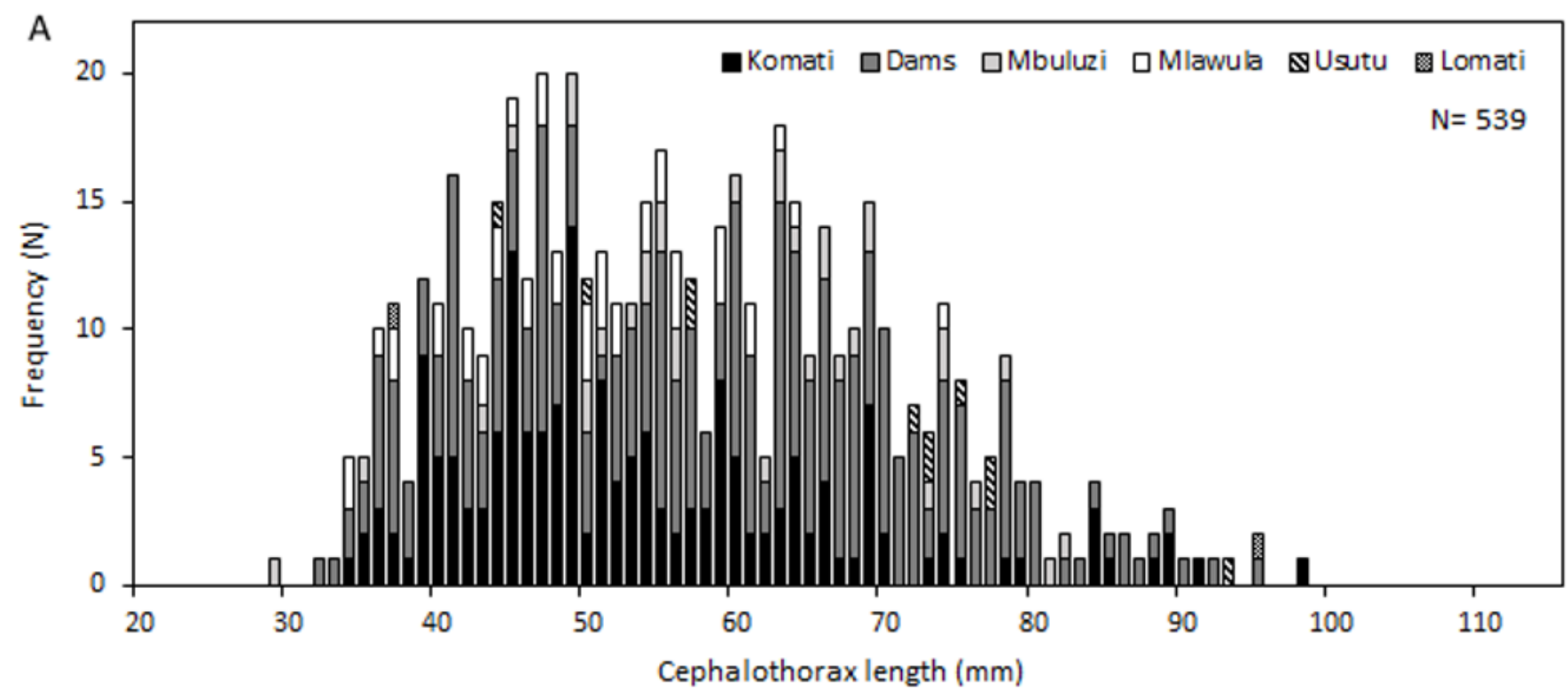

B

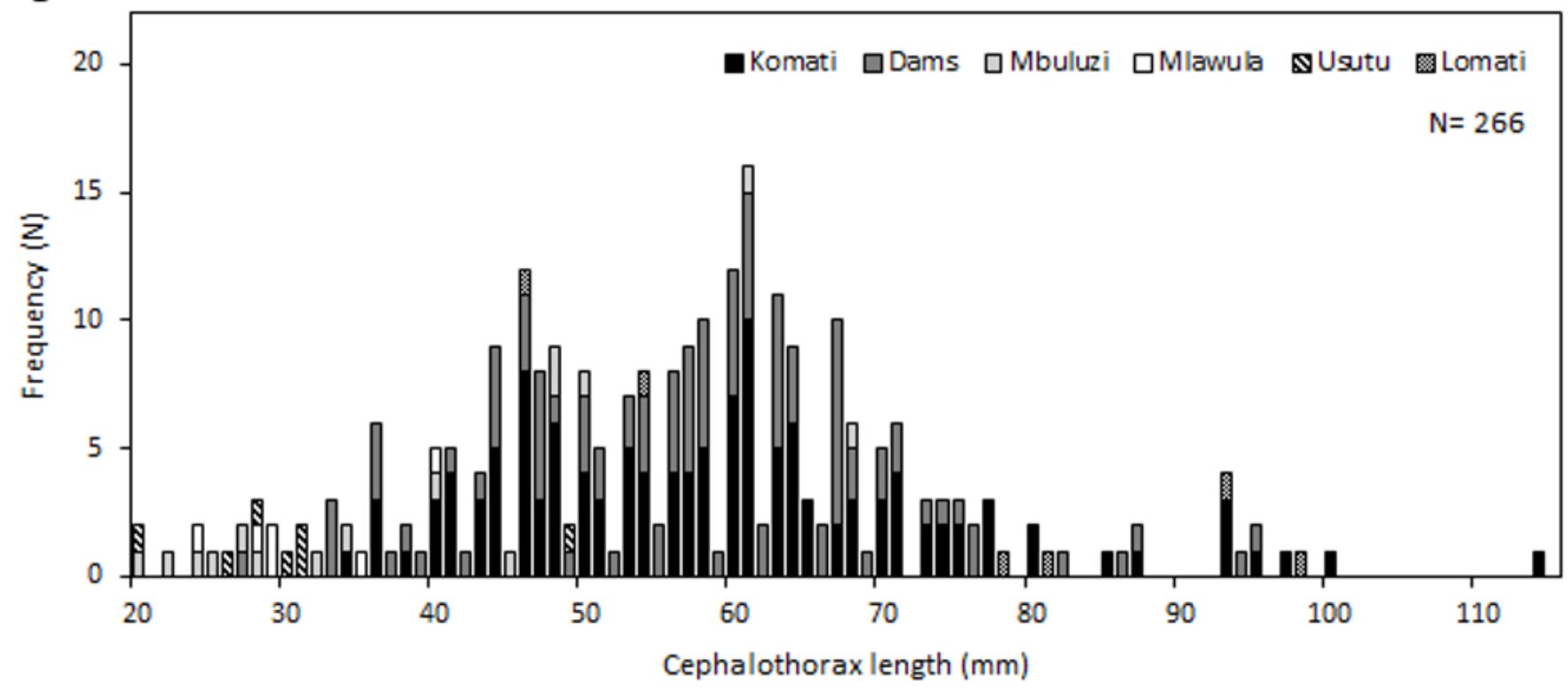


Figure 4

Relationship between size (cephalothorax length, in $\mathrm{mm}$ ) and distance to crayfish introduction source for $C$. quadricarinatus in the Komati River during the wet and dry seasons.
(A) Females and (B) Males. 

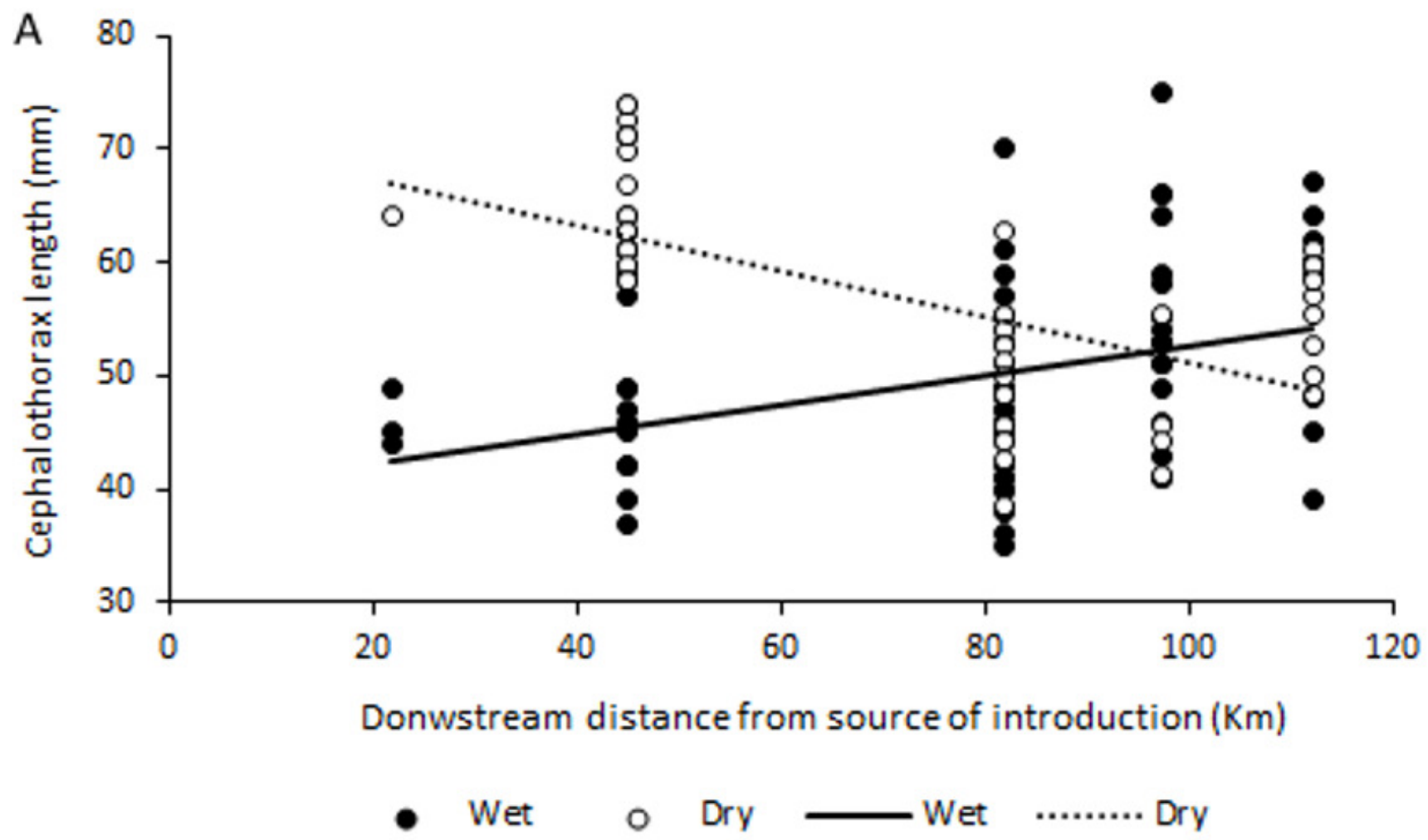

B

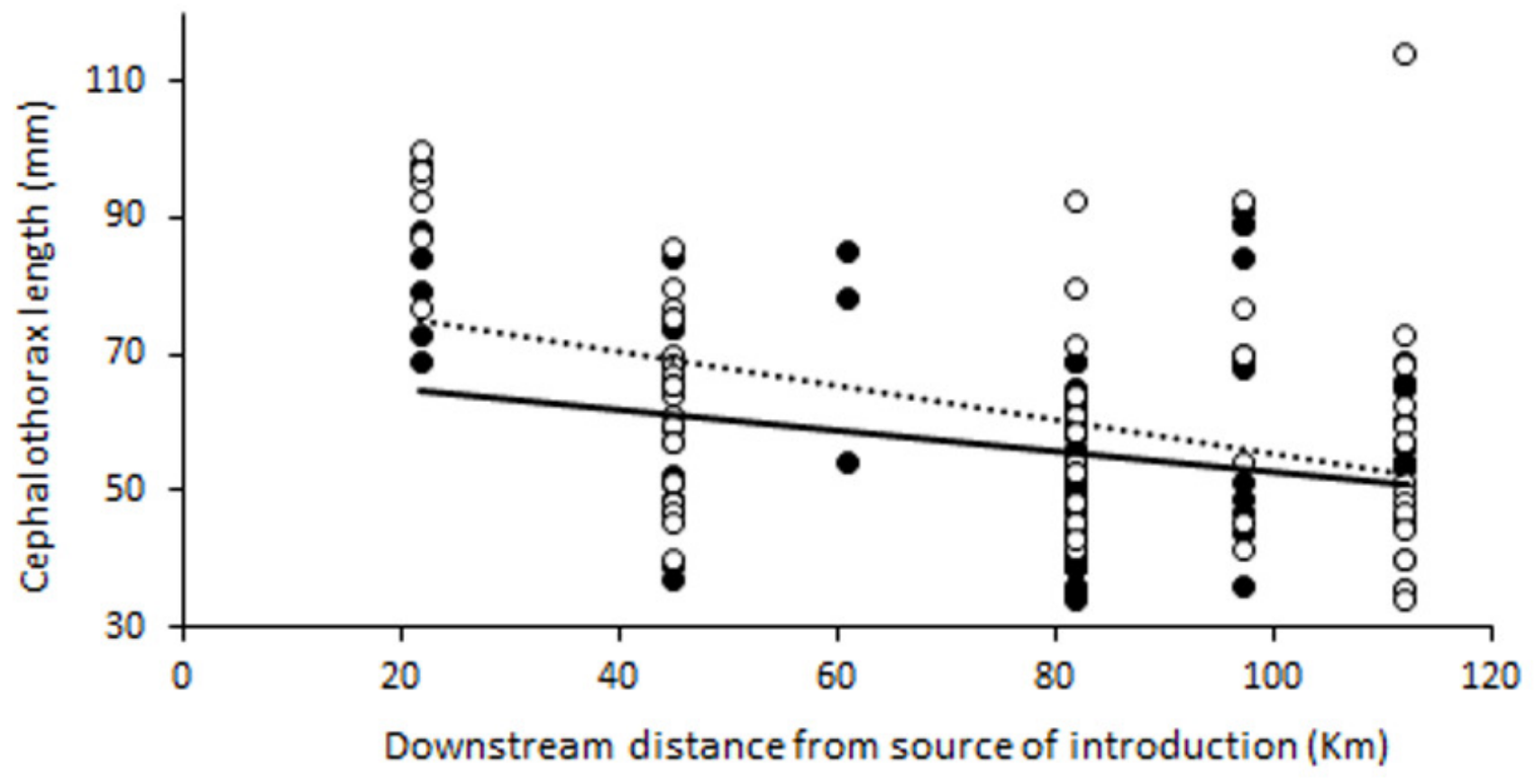

- Wet $\circ$ Dry — Wet .......... Dry 


\section{Table $\mathbf{1}$ (on next page)}

Attributes of the 22 sites where C. quadricarinatus was found.

Coordinates, location, elevation $(\mathrm{m})$, distance to closest crayfish introduction point $(\mathrm{km})$, season, catch per unit effort (CPUE, as number of individuals and biomass), average size (cephalothorax length, $\mathrm{mm}$ ), average mass $(\mathrm{g}$ ) and number of males and females, for each sampling site where crayfish was found. SD stands for standard deviation, $M$ for males, $F$ for females, SA for South Africa and SW for Swaziland. 


\begin{tabular}{|c|c|c|c|c|c|c|c|c|c|c|c|c|c|}
\hline Site & Coordinates & Location & $\begin{array}{l}\text { Elevation } \\
\text { (m) }\end{array}$ & $\begin{array}{l}\text { Distance to intro } \\
(\mathrm{km})\end{array}$ & Season & $\begin{array}{l}\text { CPUE (SD) } \\
\text { (N/trap/night) }\end{array}$ & $\begin{array}{l}\text { CPUE (SD) } \\
\text { (g/trap/night) }\end{array}$ & Size M (SD) & Size F (SD) & Mass M (SD) & Mass F (SD) & $\mathbf{M}$ & $\mathbf{F}$ \\
\hline \multirow[t]{2}{*}{ K01 } & $25^{\circ} 28^{\prime} 24.50^{\prime \prime S}$ & Komati River, SA & 130 & 112.11 & Wet & $2.2(1.39)$ & $40.48(26.42)$ & $57.17(7.28)$ & $56(9.59)$ & $50.83(19.13)$ & $49.4(22.49)$ & 12 & 10 \\
\hline & $30^{\circ} 07^{\prime 2} 23.61^{\prime \prime E}$ & & & & Dry & $3.2(5.07)$ & $33.01(32.09)$ & $53.26(19.35)$ & $50.97(7.69)$ & $34.88(26.29)$ & $32.93(14.98)$ & 17 & 15 \\
\hline \multirow[t]{2}{*}{ K02 } & $25^{\circ} 31^{\prime} 19.3 " \mathrm{~S}$ & Komati River, SA & 153 & 97.26 & Wet & $3.1(4.36)$ & $53.56(53.39)$ & $66.07(18.21)$ & $54.41(9.47)$ & 77.57 (58.17) & $39.76(21.34)$ & 14 & 17 \\
\hline & $31^{\circ} 55^{\prime} 48.2^{\prime \prime} \mathrm{E}$ & & & & Dry & $1.43(1.81)$ & $39.89(54.69)$ & $63.35(19.82)$ & $46.63(6.19)$ & $81.33(62.52)$ & $32(15.41)$ & 6 & 4 \\
\hline \multirow[t]{2}{*}{ K03 } & $25^{\circ} 32^{\prime} 45.8^{\prime \prime} \mathrm{S}$ & Komati River, SA & 174 & 81.96 & Wet & $9.4(7.73)$ & $34.71(16.73)$ & $50.08(9.04)$ & $47.55(7.79)$ & $30.65(18.63)$ & $24.07(12.55)$ & 65 & 29 \\
\hline & $31^{\circ} 50^{\prime} 59.2^{\prime \prime} \mathrm{E}$ & & & & Dry & $4.43(4.96)$ & $66.4(56.65)$ & $57.80(14.20)$ & $49.21(6.19)$ & $52.67(43.58)$ & $28.63(10.99)$ & 15 & 16 \\
\hline K04 & $\begin{array}{l}25^{\circ} 38^{\prime} 01.7^{\prime \prime S} \\
31^{\circ} 47^{\prime} 47.5^{\prime \prime} \mathrm{E}\end{array}$ & Komati River, SA & 198 & 61.11 & Wet & $0.38(0.74)$ & $23.75(44.01)$ & $72.33(16.26)$ & - & $96(64.09)$ & - & 3 & 0 \\
\hline \multirow[t]{2}{*}{ K05 } & $25^{\circ} 43^{\prime} 29.4^{\prime \prime S}$ & Komati River, SA & 233 & 44.94 & Wet & $2.88(5.49)$ & $32.42(39.75)$ & $56.92(14.69)$ & $46.55(6.85)$ & $53.17(42.59)$ & $25.09(12.37)$ & 12 & 11 \\
\hline & $31^{\circ} 46^{\prime} 49.8^{\prime \prime} \mathrm{E}$ & & & & Dry & $7(11.93)$ & $47.15(32.96)$ & $63.35(11.86)$ & $64.22(5.11)$ & $62.27(31.55)$ & $58.96(13.97)$ & 22 & 27 \\
\hline \multirow[t]{2}{*}{ K06 } & $25^{\circ} 51^{\prime} 19.4^{\prime \prime S}$ & Komati River, SA & 252 & 21.76 & Wet & $1(1.77)$ & $29.15(47.97)$ & $81.83(10.53)$ & $46(2.65)$ & $138.33(55.09)$ & $19.5(5.26)$ & 6 & 4 \\
\hline & $31^{\circ} 48^{\prime} 27.9^{\prime \prime} \mathrm{E}$ & & & & Dry & $1(1.73)$ & $50.31(89.19)$ & $91.35(8.32)$ & $64(0)$ & $202.67(45.23)$ & $58(0)$ & 6 & 1 \\
\hline \multirow[t]{2}{*}{ L01 } & $25^{\circ} 36^{\prime} 58.6^{\prime \prime S}$ & Lomati River, SA & 233 & 87.49 & Wet & $0.1(0.32)$ & $3(9.49)$ & - & $37(0)$ & - & $30(0)$ & 0 & 1 \\
\hline & $31^{\circ} 39^{\prime} 48.7^{\prime \prime} \mathrm{E}$ & & & & Dry & $0.71(0.95)$ & $40.14(68.72)$ & $76.52(16.16)$ & $45.56(0)$ & $131.5(75.44)$ & $18(0)$ & 4 & 1 \\
\hline \multirow[t]{2}{*}{ L02 } & $25^{\circ} 37^{\prime} 53.1^{\prime \prime} \mathrm{S}$ & Lomati River, SA & 236 & 89.69 & Wet & $0.1(0.32)$ & $19.2(60.72)$ & $95(0)$ & - & $192(0)$ & - & 1 & 0 \\
\hline & $31^{\circ} 39^{\prime} 19.0^{\prime \prime} \mathrm{E}$ & & & & Dry & $0(0)$ & $0(0)$ & - & - & - & - & 0 & 0 \\
\hline \multirow[t]{2}{*}{ L03 } & $25^{\circ} 38^{\prime} 55.9^{\prime \prime} \mathrm{S}$ & Lomati River, SA & 238 & 93 & Wet & $0(0)$ & $0(0)$ & - & - & - & - & 0 & 0 \\
\hline & $31^{\circ} 40^{\prime} 10.7^{\prime \prime} \mathrm{E}$ & & & & Dry & $0.2(0.45)$ & $38(84.97)$ & - & $98.24(0)$ & - & $190(0)$ & 0 & 1 \\
\hline \multirow[t]{2}{*}{ MB01 } & $26^{\circ} 08^{\prime} 05.6^{\prime \prime S}$ & Mbuluzi River, SW & 163 & 23.14 & Wet & $4.5(6.63)$ & $19.78(24.01)$ & $62.65(10.12)$ & $54.4(12.35)$ & $53.65(24.28)$ & $37.3(29.32)$ & 17 & 10 \\
\hline & $31^{\circ} 59^{\prime} 48.4^{\prime \prime} \mathrm{E}$ & & & & Dry & $1(1.41)$ & $11.19(14.48)$ & $29.2(7.05)$ & $27.33(7.02)$ & $17.4(12.19)$ & $15.33(11.68)$ & 5 & 3 \\
\hline \multirow[t]{2}{*}{ MB02 } & $26^{\circ} 10^{\prime} 00.5^{\prime \prime} \mathrm{S}$ & Mbuluzi River, SW & 194 & 6.06 & Wet & $1(1.41)$ & $24.21(34.31)$ & $63.17(18.76)$ & $58(5.66)$ & $69.83(42.83)$ & $41(11.31)$ & 6 & 2 \\
\hline & $31^{\circ} 53^{\prime} 50.7^{\prime \prime} \mathrm{E}$ & & & & Dry & $1(1.41)$ & $44.38(56.99)$ & $49.2(16.93)$ & $49(1.41)$ & $120(87.56)$ & $81(5.66)$ & 5 & 2 \\
\hline \multirow[t]{2}{*}{ ML01 } & $26^{\circ} 10^{\prime} 34.6^{\prime \prime S}$ & Mlawula River, SW & 147 & 47.5 & Wet & $1.57(2.44)$ & $8.99(12.56)$ & $49.29(12.27)$ & $40.75(3.59)$ & $30.43(33.11)$ & $13(3.92)$ & 7 & 4 \\
\hline & $31^{\circ} 59^{\prime} 28.8^{\prime \prime} \mathrm{E}$ & & & & Dry & $0(0)$ & $0(0)$ & - & - & - & - & 0 & 0 \\
\hline \multirow[t]{2}{*}{ ML02 } & $26^{\circ} 11^{\prime} 16.4^{\prime \prime S}$ & Mlawula River, SW & 155 & 50 & Wet & $4(3.67)$ & $21.97(14.24)$ & $51.38(8.39)$ & $49.91(7.18)$ & $30.67(16.48)$ & $27.09(11.47)$ & 21 & 11 \\
\hline & $31^{\circ} 59^{\prime} 12.4^{\prime \prime} \mathrm{E}$ & & & & Dry & $0.86(0.9)$ & $10.71(11.22)$ & $29(0)$ & $31.2(6.30)$ & $13(0)$ & $21.8(14.06)$ & 1 & 5 \\
\hline \multirow[t]{2}{*}{ US01 } & $26^{\circ} 46^{\prime} 57.5^{\prime \prime} \mathrm{S}$ & Usutu River, SW & 79 & - & Wet & $0.8(2.53)$ & $7.84(24.78)$ & $71.8(17.68)$ & $68.33(9.87)$ & $85.2(55.78)$ & $67(25.24)$ & 5 & 3 \\
\hline & $31^{\circ} 59^{\prime} 04.3^{\prime \prime} \mathrm{E}$ & & & & Dry & $0.57(1.13)$ & $11.43(23.61)$ & $34.5(9.75)$ & - & $28.50(23.06)$ & - & 4 & 0 \\
\hline \multirow[t]{2}{*}{ US02 } & $26^{\circ} 51^{\prime} 26.8^{\prime \prime} \mathrm{S}$ & Usutu River, SW & 95 & - & Wet & $0.1(0.32)$ & $2.2(6.96)$ & $50(0)$ & - & $22(0)$ & - & 1 & 0 \\
\hline & $31^{\circ} 54^{\prime} 29.3^{\prime \prime} \mathrm{E}$ & & & & Dry & $0.14(0.38)$ & $2.43(6.43)$ & $31(0)$ & - & $17(0)$ & - & 1 & 0 \\
\hline \multirow[t]{2}{*}{ USCh } & $26^{\circ} 50^{\prime} 51.0^{\prime \prime} \mathrm{S}$ & Channel by Usutu, SW & 125 & - & Wet & $0.67(1.16)$ & $22.67(39.26)$ & $67(14.14)$ & - & $68(39.59)$ & - & 2 & 0 \\
\hline & $31^{\circ} 54^{\prime} 49.8^{\prime \prime} \mathrm{E}$ & & & & Dry & $0.29(0.76)$ & $1.86(4.91)$ & $26(0)$ & $20(0)$ & $11(0)$ & $15(0)$ & 1 & 1 \\
\hline \multirow[t]{2}{*}{ D01 } & $25^{\circ} 33^{\prime} 08.1^{\prime \prime S}$ & Dam, SA & 190 & - & Wet & $15.3(19.98)$ & $64.51(35.17)$ & $66.34(10.45)$ & $62.06(10.78)$ & $78.39(37.87)$ & $59.42(34.24)$ & 118 & 35 \\
\hline & $31^{\circ} 54^{\prime} 16.0^{\prime \prime} \mathrm{E}$ & & & & Dry & $1.75(2.12)$ & $46.87(33.26)$ & $65.19(12.02)$ & $59.5(16.36)$ & $73.23(48.46)$ & $50(46.78)$ & 26 & 9 \\
\hline \multirow[t]{2}{*}{ D02 } & $25^{\circ} 32^{\prime} 57.1^{\prime \prime S}$ & Dam, SA & 186 & - & Wet & $3.3(2.83)$ & $40.89(19.09)$ & $59.18(9.62)$ & $53.86(8.83)$ & $53.11(26.12)$ & $36.67(15.98)$ & 18 & 15 \\
\hline & $31^{\circ} 53^{\prime} 37.0^{\prime \prime} \mathrm{E}$ & & & & Dry & $1.9(4.09)$ & $13.22(23.20)$ & $56.12(11.36)$ & $54.5(8.42)$ & $45.8(25.45)$ & $37.78(16.11)$ & 10 & 9 \\
\hline D03 & $25^{\circ} 37^{\prime} 14.4^{\prime \prime S}$ & Dam, SA & 190 & - & Wet & $2.67(3.68)$ & $36.77(49.89)$ & $66.71(13.33)$ & $65.27(14.28)$ & $84.95(53.81)$ & $74.91(49.93)$ & 21 & 11 \\
\hline
\end{tabular}




\begin{tabular}{|c|c|c|c|c|c|c|c|c|c|c|c|c|c|}
\hline & $31^{\circ} 51^{\prime} 42.3^{\prime \prime} \mathrm{E}$ & & & & & & & & & & & & \\
\hline \multirow[t]{2}{*}{ D04 } & $25^{\circ} 32^{\prime} 41.2^{\prime \prime} \mathrm{S}$ & Dam, SA & 188 & - & Wet & $1.11(1.27)$ & $49.44(52.00)$ & $69.57(16.27)$ & $53.33(15.04)$ & $102(52.51)$ & $54(6.93)$ & 7 & 3 \\
\hline & $31^{\circ} 50^{\prime} 20.3^{\prime \prime} \mathrm{E}$ & & & & Dry & $5.57(6.45)$ & $42.48(21.24)$ & $61.44(8.49)$ & $51.4(11.73)$ & $55.05(27.89)$ & $33.47(21.11)$ & 19 & 19 \\
\hline \multirow[t]{2}{*}{ D05 } & $25^{\circ} 51^{\prime} 52.5^{\prime \prime} \mathrm{S}$ & Dam, SA & 265 & - & Wet & $7.4(8.93)$ & $16.05(11.68)$ & $46.44(9.97)$ & $42.15(5.78)$ & $26.35(15.97)$ & $17.36(8.89)$ & 46 & 28 \\
\hline & $31^{\circ} 50^{\prime} 00.9^{\prime \prime} \mathrm{E}$ & & & & Dry & $0.9(1.10)$ & $19.97(26.92)$ & $50.97(13.26)$ & $53.39(10.99)$ & $36.8(27.73)$ & $36(15.41)$ & 5 & 4 \\
\hline \multirow[t]{2}{*}{ D06 } & $25^{\circ} 58^{\prime} 43.6^{\prime \prime S}$ & Sand River Dam, SW & 295 & - & Wet & $0.13(0.35)$ & $1.13(3.18)$ & $38(0)$ & - & $9(0)$ & - & 1 & 0 \\
\hline & $31^{\circ} 42^{\prime} 42.8^{\prime \prime} \mathrm{E}$ & & & & Dry & $0.38(0.74)$ & $5.38(10.04)$ & $33(0)$ & $27(0)$ & $24.5(0.71)$ & $13(0)$ & 2 & 1 \\
\hline
\end{tabular}

1 